\title{
Air Pollution - A Problematic Issue
}

\section{OPEN ACCESS}

Manuscript ID:

ASH-2020-08013227

Volume: 8

Issue: 1

Month: July

Year: 2020

P-ISSN: 2321-788X

E-ISSN: 2582-0397

Received: 15.05 .2020

Accepted: 03.06.2020

Published: 02.07.2020

Citation:

Jafari Shalkouhi, P. "Air

Pollution - A Problematic

Issue." Shanlax

International Journal

of Arts, Science and

Humanities, vol. 8 ,

no. 1,2020 , pp. 231-232.

DOI:

https://doi.org/10.34293/

sijash.v8i1.3227

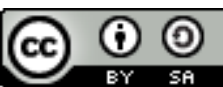

This work is licensed under a Creative Commons Attribution-ShareAlike 4.0 International License

\author{
P. Jafari Shalkouhi \\ Department of Environmental Engineering \\ Faculty of Natural Resources and Environment, Science and Research Branch \\ Islamic Azad University, Tehran, Iran \\ https://orcid.org/0000-0001-8657-415X
}

\begin{abstract}
Air pollution is considered as a universal issue with consequences varying from the deaths of people and plants to declining crop yields and damaged buildings. "Poems that clean the air we breathe could help tackle pollution." This paper presents a new poem about air pollution. This paper also indicates that most of the poems in the area of air pollution are embodied in magazines/ websites rather than academic journals. Hence, the present author hopes to find more poems in academic journals in the future about air pollution and related sciences.
\end{abstract}

Keywords: Air pollution, Death, Poem, Academic journal, Magazine and Website

In general, the actions of people are the primary cause of pollution, and as the population increases, the attendant pollution problems also increase proportionately. The first significant change in man's effect on nature came with his discovery of fire. Prehistoric man built a fire in his cave for cooking, heating, and to provide light. The problem of air pollution came into existence at this time. The dispersal of pollutants discharged near the ground level is dependent upon the prevailing wind speed and wind direction.

Air pollution is a universal problem with consequences raging from the deaths of people and plants to declining crop yields and damaged buildings. For instance, around 33,000 people die each year in Iran because of pollution in the air, water, and so on. Also, Zabol city, situated in the southeast of Iran, is the most polluted place in the world about PM 2.5.

"Poems that clean the air we breathe could help tackle pollution". Post Bulletin reported that "students show environmental concern with poems, prose." Most of the poems in the area of air pollution are embodied in magazines/websites including Champak, Poem Hunter, The Poetry of Science, Hello Poetry, Poetry of Scotland, Poetry Soup, Dodoland, Edugreen, Quora, Tunza Eco Generation, Voices Net, etc. In other words, there are little air pollution poems in academic journals. For example, Stewart wrote a poem about acidic snow (his poem is also included in the Ecology Online Sweden. Also, Harini reviewed the air pollution poem written by the poet "Abhisumat Singh." Hence, a poem composed by the author of the present paper about air pollution is appended below:

- Acid rain causes damage to vegetation

- Inversion of temperature increases air pollution

- Rain cleans the atmosphere

- Pollutants do not disperse in the stratosphere

- Ozone is a common pollutant in major cities

- Lead exposure causes heart disease

- Lung irritation can be due to inhaling sulfur dioxide

- Urban air quality is affected by the level of carbon monoxide 
- Trucks are mobile sources of air pollutants

- Industrial boilers produce considerable air contaminants

- $\mathbf{O}_{3}$ is a colorless to bluish gas

- $\mathrm{NO}_{2}$ can arise from the burning of biomass.

In conclusion, the present author hopes to find more poems in academic journals in the future about air pollution and related sciences.

\section{Glossary}

Acid rain/ snow: any form of precipitation with chemical components that cause environmental harm.

Biomass: any organic matter which is available on a renewable basis such as forest residues, crops, etc.

Inversion of temperature: an increase rather than a decrease of temperature with altitude

$\mathrm{NO}_{2}$ : nitrogen dioxide

$\mathbf{O}_{3}$ : ozone

Stratosphere: the upper layer of the atmosphere (between approximately 10-50 kilometers above the earth's surface).

\section{References}

Aditi. Pollution, Champak Magazine, http://www. champak.in/poems/pollution

Air-cleansing Poetry: Poems that Clean the Air we Breathe could help Tackle Pollution, Sheffield University, 2017, https://www.sheffield. ac.uk/news/nr/catalytic-poem-air-cleansingpollution-sheffield-1.673043

Andalib, Asif. Air Pollution in Cities, Poetry Soup, 2012, https://www.poetrysoup.com/poem/ air_pollution_in_cities_424931

Baba. Pollution, Poetry of Scotland, 2004, www. poetryofscotland.co.uk/Other/pollution.php.

Boulding, K.E. http://edugreen.teri.res.in/misc/ poem/poem.htm
Colls, Jeremy. Air Pollution, Spon Press, London, 2002.

Dias, Menu. Pollution, Hello Poetry, 2012, https:// hellopoetry.com/words/pollution.

Gupta, Biman Gati, et al. "Air Pollution from Bleaching and Dyeing Industries Creating Severe Health Hazards in Maheshtala Textile Cluster, West Bengal, India." Air, Soil and Water Research, vol. 10, 2017.

Illingworth, Sam. Diabetic Breath, The Poetry of Science, 2018, https://thepoetryofscience. scienceblog.com/640/diabetic-breath/\#more -640 .

Mudakavi, J.R. Principles and Practices of Air Pollution Control and Analysis, I.K. International Pvt Ltd, 2010.

Peng, Minggang. "Actual Air Pollution, Environmental Transparency, and the Perception of Air Pollution in China." The Journal of Environment \& Development, vol. 28, no. 1, 2019, pp. 78-105.

Rao, M.N. and H.V.N. Rao. Air Pollution, Tata McGraw-Hill, 1989.

Singh, Abhisumat. Air Pollution, Poem Hunter, 2001, https://www.poemhunter.com/poem/ air-pollution.

Smith, Oliver. Is Delhi the Most Polluted City on Earth? Not quite, The Telegraph, 2017, http:// www.telegraph.co.uk/travel/destinations/ asia/india/articles/delhi-most-polluted-cityin-the-world.

Students show Environmental Concern with Poems, Prose, Post Bulletin, 1992, https:// www.postbulletin.com/students-showenvironmental-concern-with-poemsprose/article 4ebea859-9906-511f-8aa283d9313e6090.html.

Unhealthy Environment Kills 33,000 Iranians Annually, Tehran Times, 2017, https:/www. tehrantimes.com/news/417568/Unhealthyenvironment-kills-33-000-Iranians-annually

\section{Author Details}

P. Jafari Shalkouhi, Department of Environmental Engineering, Faculty of Natural Resources and Environment, Science and Research Branch, Islamic Azad University, Tehran, Iran, Email ID: pedram121212@yahoo.com 